\title{
THE EYE AND RELATED GLANDS OF THE RAT AND PIG IN PROTEIN DEFICIENCY*
}

\author{
BY \\ D. S. MCLAREN† \\ Human Nutrition Research Unit, National Institute for Medical Research, Mill Hill, London
}

ProteIn malnutrition has been described (Brock and Autret, 1952) as "the most serious and widespread nutritional disorder known to medical and nutritional science". Dietary and other differences lead to variations on a basic theme in the descriptions of the condition from different parts of the world. Retardation of growth and development, apathy and peevishness, changes in texture and colour of the hair, a characteristic "crazy-pavement dermatosis", fatty infiltration of the liver, oedema, and changes in the serum proteins are some of the main and most constant features.

The eye is not commonly described as being affected, and when it is, the changes are usually attributed to an accompanying vitamin deficiency, particularly of vitamin A (McLaren, 1958a). Little is known of the effects of protein deficiency on the eye of experimental animals. Sydenstricker, Hall, Hock, and Pund (1946) described corneal vascularization in rats fed a proteinfree diet from 50 days of age. The same group of workers showed that a deficiency of each of the essential amino acids may also cause corneal vascularization, and that, with the single exception of arginine, lenticular changes also occur (Hall, Bowles, Sydenstricker, and Schmidt, 1948). The sole observation in this field on the pig seems to be that of Cartwright, Wintrobe, Buschke, Follis, Suksta, and Humphreys (1945), in which some of the pigs fed diets primarily characterized by lack of tryptophan developed cataract.

Recent work in this laboratory indicates that in some respects the pig is more suitable than the rat for the study of protein malnutrition (Knowles, 1957). The present work comprises a study of the changes in the eye of both rats and pigs weaned on to diets low in protein.

Methods
Animals
Rats.-These were Wistar albino stock, reared in the Human Nutrition Research Unit
colony, and known as Glaxo as they were originally obtained from Glaxo laboratories
6 years ago. The rats were housed in wire cages suspended over trays of sawdust, and
supplied with open food pots and with water bottles placed on the top of each cage. For
experiments lasting a short time, the rats were kept in individual cages. In long-term
studies they were kept segregated by sex, in numbers up to four in a large cage. Food
and water were supplied ad libitum.

* Received for publication December 13, 1957.

$\dagger$ Present address: East African Institute for Medical Research, Mwanza, Tanganyika. 
Pigs.-Animals from four litters were studied, being born from crosses between Wessex Saddleback sows and Wessex Saddleback, Large White, or Landrace boars. They were kept indoors, in trolley pens with a wire mesh floor. Usually not more than two pigs were kept in one pen. They were fed food and water ad libitum.

\section{Diets}

Rats.-Four low-protein diets were used. Their composition is shown in Table I, together with the approximate percentage of protein supplied by each. All animals received an oral supplement of the fat-soluble vitamins weekly. The B vitamins were provided by yeast in the case of Diets 1 and 2 and by oral supplements to animals fed Diet 3. Rats fed the brown cassava diet (Diet 4) did not receive the B vitamin supplement. Animals were weaned on to the diets at 21 days of age, except in the case of the non-protein diet, Diet 3, when they were fed diets containing varying levels of protein until 50 days of age.

TABLE I

COMPOSITION OF LOW PROTEIN DIETS FED TO RATS

\begin{tabular}{|c|c|c|c|c|c|c|c|}
\hline \multicolumn{4}{|l|}{ Diet } & 1 & 2 & 3 & 4 \\
\hline $\begin{array}{l}\text { Constituent } \\
\text { (per cent.) }\end{array}$ & $\begin{array}{ll}\text { Maize Starch } & . . \\
\text { Casein .. } & . \\
\text { Arachin .. } & \ldots \\
\text { Salt Mixture } & \ldots \\
\text { Yeast .. } \\
\text { Brown Cassava }\end{array}$ & $\begin{array}{l}\ldots \\
\ldots \\
\ldots \\
\cdots \\
.\end{array}$ & $\begin{array}{l}\cdots \\
\cdots \\
\cdots \\
\cdots \\
\cdots\end{array}$ & $\begin{array}{r}92 \\
3 \\
3 \\
2 \\
-\end{array}$ & $\begin{array}{l}92 \\
3 \\
3 \\
2 \\
-\end{array}$ & $\frac{97}{\frac{7}{3}}$ & $\frac{\bar{Z}}{\frac{3}{97}}$ \\
\hline \multicolumn{2}{|c|}{ Approximate per cent. Protein .. } & 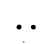 & . & 4 & 4 & - & 1 \\
\hline
\end{tabular}

DieT 1.-On this diet the growth of rats was retarded but steady, and they reached about half of the normal adult body weight. They have been followed for over 2 years, during which time they have been active and apparently healthy. About $10 \mathrm{~g}$. diet per day were consumed by each rat. This diet was very low in fat and the yeast supplied less of the B vitamins than is recommended for normal rats. However, supplementing with B vitamins failed to increase the rate of growth, and the amounts supplied would seem to be adequate for these rats consuming only 4 per cent. protein in the diet. The males were infertile, but in the case of a single female a litter with eye defects was obtained from a mating with a stock male. These changes have been reported elsewhere (McLaren, 1957).

DIET 2.- This was identical to Diet 1, except that arachin, a protein from groundnut, replaced casein. Rats have been kept for 8 months on this diet up to the present time. They achieve only about one-third or one-quarter of the body weight of controls, but appear active and generally healthy. They are quite infertile.

DIET 3.-This diet was devoid of protein and rats steadily lost weight on it, though even so they survived for a varying number of weeks, and those which had previously been fed the best diet lived for nearly 3 months.

Diet 4.-Rats fed this diet tended to lose weight slowly and to die after a varying number of weeks. The length of survival seemed to depend in part upon the weaning weight, being longest in those with the highest weaning weights. 
With the exception of Diet 3, these diets simulated to some extent diets low in protein which are commonly consumed by certain malnourished human communities. Like these diets too, they were also low in fat and the B vitamins.

Pigs.-Control animals were fed Amvilac (Glaxo) No. 1 from weaning, followed by Amvilac No. 2. In both these diets the level of protein was over 20 per cent., and the main source of protein was milk powder in the first and fishmeal in the second.

The low protein diet had the following composition:

\begin{tabular}{|c|c|c|c|}
\hline Ingredient & & & Percentage \\
\hline Whole whea & .. & & \\
\hline Haricot beans & . & .. & 2 \\
\hline $\mathbf{M}$ & . & .. & 61 \\
\hline fmeal & .. & .. & 2 \\
\hline ture & .. $\quad .$. & 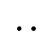 & 3 \\
\hline oil (plus & D 50 i.u./g. & & 2 \\
\hline
\end{tabular}

An analysis showed that this supplied adequate amounts of the main B complex vitamins. The protein content was about 4.5 per cent. Pigs fed this diet grew very slowly and frequently died after about 4 or 6 months, showing many of the signs already mentioned as characterizing human protein malnutrition. Those which survived more than one year showed interesting changes in the eyes which are referred to later.

\section{Results}

Rats. - The eyes of rats on the stock and experimental diets were examined with the naked eye and the ophthalmoscope at regular intervals. Examination with the slit-lamp microscope was also undertaken at weekly intervals or more frequently when changes were occurring. Immediately after death the eyes and pieces of the Harderian and lacrimal glands were taken for histological and histochemical examination.

Diet 1.-Forty rats were kept on this diet from weaning for periods varying up to over 2 years. 25 rats from the same litters were kept as controls on stock diet. All the rats were more than one year old. By all the methods of examination mentioned above no abnormalities were detected in any of these rats in any part of the eye or in the associated glands. However, it has been shown in this laboratory, and reported elsewhere (Platt, McLaren, and Bagchi, 1957), that animals on this diet have a reduced concentration of sulphydryl groups in the lens.

Diet 2.-Fourteen rats were fed this diet from weaning. Without exception these animals developed vascularization of the cornea of both eyes within one month of starting to consume the diet. Within 2 or 3 weeks the vessels had extended to reach almost to the centre of the cornea. They were situated sub-epithelially and were surrounded by an elliptical area of haziness. On histological examination the basal cells in the neighbourhood of the invading capillaries were seen to be swollen, and this may have been responsible for the haziness. This change was even more marked in rats fed Diet 4, as will be described later. 
It will be recalled that the only difference between Diets 1 and 2 was that the former contained casein while the latter contained arachin. The amount of sulphur-containing amino acids supplied by Diet 1 was only about onetenth of that in the stock diet, Diet 41B (Bruce and Parkes, 1956), but the amount in Diet 2 was even less, only about one-twentieth of that in Diet 41B. This difference was thought to be the determining factor in the different response on the two diets. This was supported by the fact that vascularization could be prevented by supplementing Diet 2 with d1-methionine, and could be reversed by the same means once it had developed.

Changes were not found in any other parts of the eye or in the glands.

Diet 3.-On this protein-free diet rats developed marked changes in cornea, conjunctiva, and Harderian and lacrimal glands. The occurrence of corneal vascularization previously reported in rats on a protein-free diet was confirmed. A small experiment was designed to show whether the initial level of protein in the diet affected the time of onset of vascularization. A litter of six rats was divided into three pairs, one male and one female in each. Each pair was weaned when 21 days old on to a different diet, the only difference being that the respective levels of protein were 4,11 , and 18 per cent., the diets being adequate in all other respects. When 50 days of age all the rats were fed Diet 3 . One rat in each pair developed corneal vascularization, and one rat died without showing it. Table II shows that vascularization appeared, in the three rats which showed it, earliest in the one which had been on the lowest level of protein, next in that on the intermediate diet, and last in that on the best diet. The periods for which the other three rats survived without showing vascularization are in the same order. It would seem then that, under the conditions of the experiment, when the animals were taking in no protein after the 50th day, the onset of vascularization was an indication that a certain stage of depletion of body

TABLE II

RESULTS OF EXPERIMENT USING DIET 3

\begin{tabular}{c|c|c|c|c}
\hline Animal No. & Sex & $\begin{array}{c}\text { Initial Diet } \\
\text { (Per cent. Protein) }\end{array}$ & $\begin{array}{c}\text { Day of Onset } \\
\text { of } \\
\text { Vascularization }\end{array}$ & $\begin{array}{c}\text { Day of Death } \\
\text { if No } \\
\text { Vascularization }\end{array}$ \\
\hline 1 & M & 18 & 138 & - \\
2 & F & - & 174 \\
\hline 3 & M & 11 & - & 127 \\
4 & F & 99 & - \\
\hline 5 & M & 4 & - & 74 \\
\hline 6 & F & 4 & 65 & - \\
\hline
\end{tabular}


protein had been reached. The animals which had the larger stores to start with took longer to reach this state.

The vascularization was indistinguishable from that described already in rats fed Diet 2. In addition, in the later stages of the process in rats fed Diet 3, the epithelium had a "snowstorm" appearance on slit-lamp examination, similar to that seen in vitamin A deficiency. Fig. 1 shows two subepithelial vessels in section and the changes in the epithelium. These consist of a thinning of the layers, with marked loss of cytoplasm and degeneration of the nuclei of the deeper layers, and keratinization of superficial cells (cf. Fig. 2, which shows normal rat cornea, but note the difference in magnification).

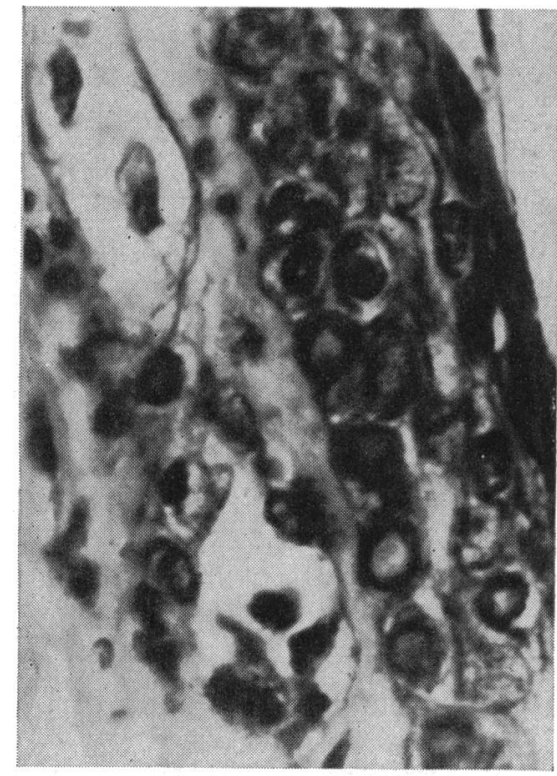

FIG. 1.-Epithelium and superficial stroma of cornea in a rat fed Diet 3 . Haematoxylin and eosin. $\times 1200$.

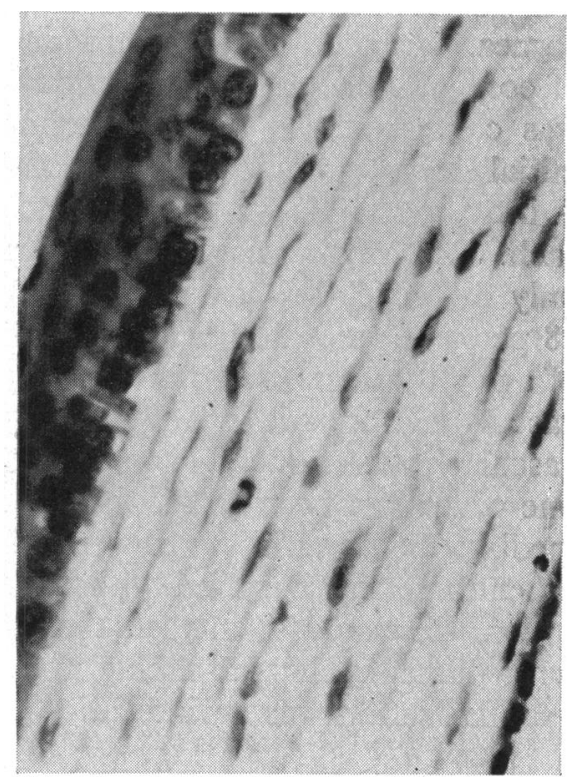

Fig. 2.-Normal rat cornea. Haematoxylin and eosin. $\times 500$.

In the terminal stages, rats fed this diet had marked chemosis with sticking together of the lids. There was no porphyrin incrustation of the lids. The conjunctiva showed changes similar to those described in the cornea. With the periodic acid-Schiff method (P.A.S.) goblet cells were no longer visible, and a thin layer of P.A.S.-positive material was spread along the epithelial surface.

Very marked changes were seen in the glands, especially in the Harderian gland. These consisted of atrophy of the whole gland, early infiltration with round cells, and shrinking down of the cytoplasm of the acinar cells. Only in the Harderian gland were the acini filled with granular debris and actual degeneration of the acinar cells was seen (Fig. 3, opposite). The normal rat Harderian gland is shown in Fig. 4 (opposite) for comparison.

The rest of the eye showed no changes. 


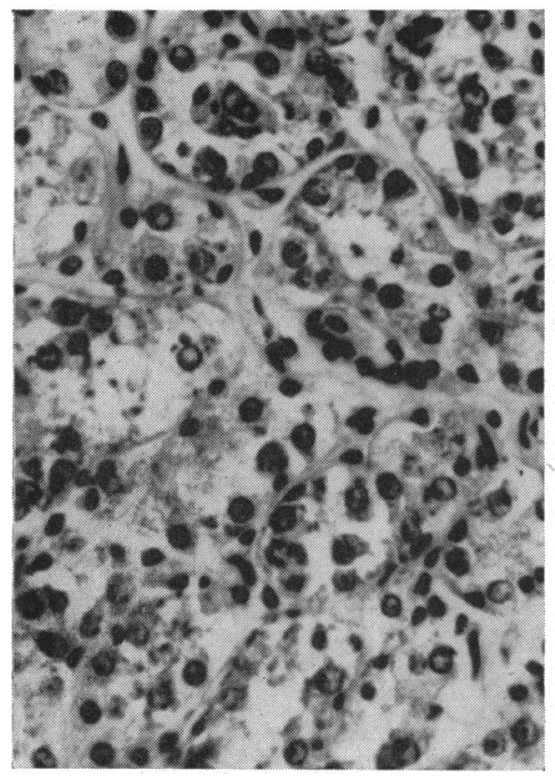

Fig. 3.- Harderian gland of a rat fed Diet 3. Haematoxylin and eosin. $\times 500$.

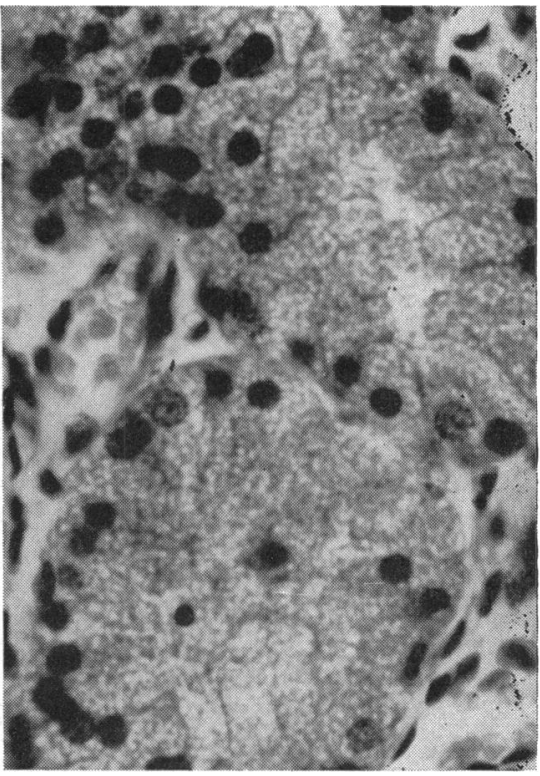

Fig. 4.-Normal rat Harderian gland. Haematoxylin and eosin. $\times 500$.

Diet 4.-In all, 73 rats were fed this diet. In the terminal stages, chemosis, with incrustation of the lids with porphyrin secretion, was seen in many of the animals. Under the slit lamp the secretion appeared fatty and was seen to be partly yellowish and partly brownish. The latter was presumably from the Harderian gland and gave a brick-red fluorescence in ultra-violet light. At about the same time vascularization of the cornea developed with a general haziness similar to that already described in rats fed Diet 3. Fig. 5, showing the typical appearance of the cornea of rats on this diet. should be compared with Fig. 2. The corneal epithelium consists of only two or three layers, instead of the usual five or six. This seems to be due to an arrest in the division of the basal cell layer, for, unlike the appearance in vitamin A deficiency, these cells are markedly abnormal. They appear to be blown up, with large bladder-like areas of cytoplasm, and the nuclei are dense and pyknotic. The basal cells appear to be oedematous rather than merely empty; they closely resemble the appearances seen in the condition known as bullous keratitis in man, and also seen in the corneae of rats which have been cauterized.

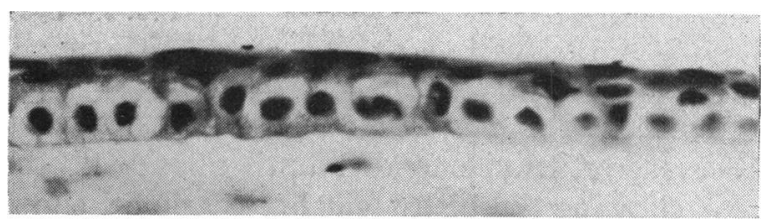

FIG. 5.-Abnormal appearance of corneal epithelium of a rat fed Diet 4. Haematoxylin and eosin. $\times 500$. 
Glandular changes were less marked (Fig. 6) than those described in rats fed Diet 3, and the lacrimal was less affected than the Harderian gland. Changes were not seen in other parts of the eye. Diet 4 supplied a very little amount of the B complex vitamins and this deficiency may have played a part.

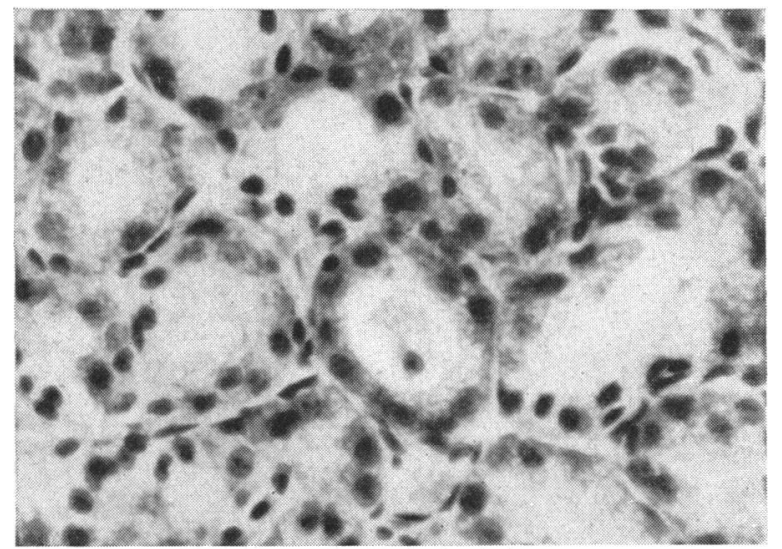

Fig. 6.-Harderian gland of a rat fed Diet 4. Haematoxylin and eosin. $\times 500$.

Pigs.-Fourteen pigs were examined with the naked eye and with the ophthalmoscope. Most of these were less than one year old, and in these no changes were seen in vivo or histologically.

In the two pigs which lived for more than one year striking changes occurred, and these will be described in detail. The part of the eye showing the most marked change was the lens. In each of these two pigs bilateral cataract developed (Figs 7 and 8).

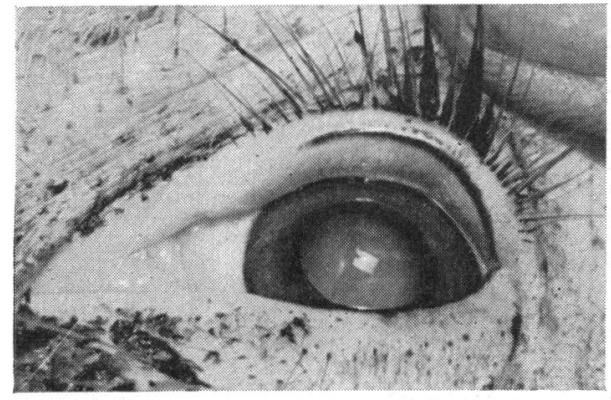

FIG. 7.-Eye of pig 4/1.

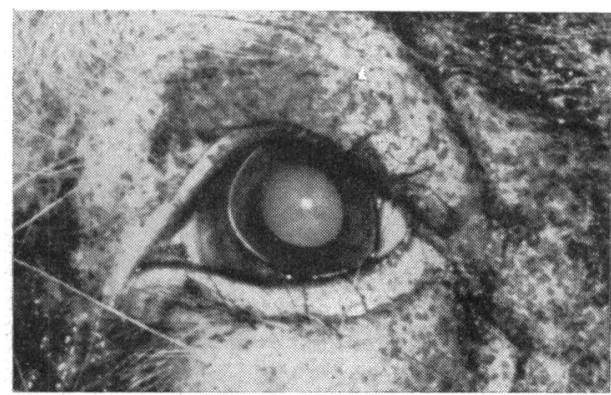

Fig. 8.-Eye of pig 3/1.

The earliest changes consisted of a swelling of the lens fibres in the region of the equator, with separation of the fibres by vacuoles of varying size. This process gradually extended until all the fibres were involved. Fig. 9 (opposite), showing the histological appearance, should be compared with Fig. 10 (opposite) from a control pig. 
FIG. 9.-Lens of pig 4/1. Haematoxylin and eosin. $\times 125$.
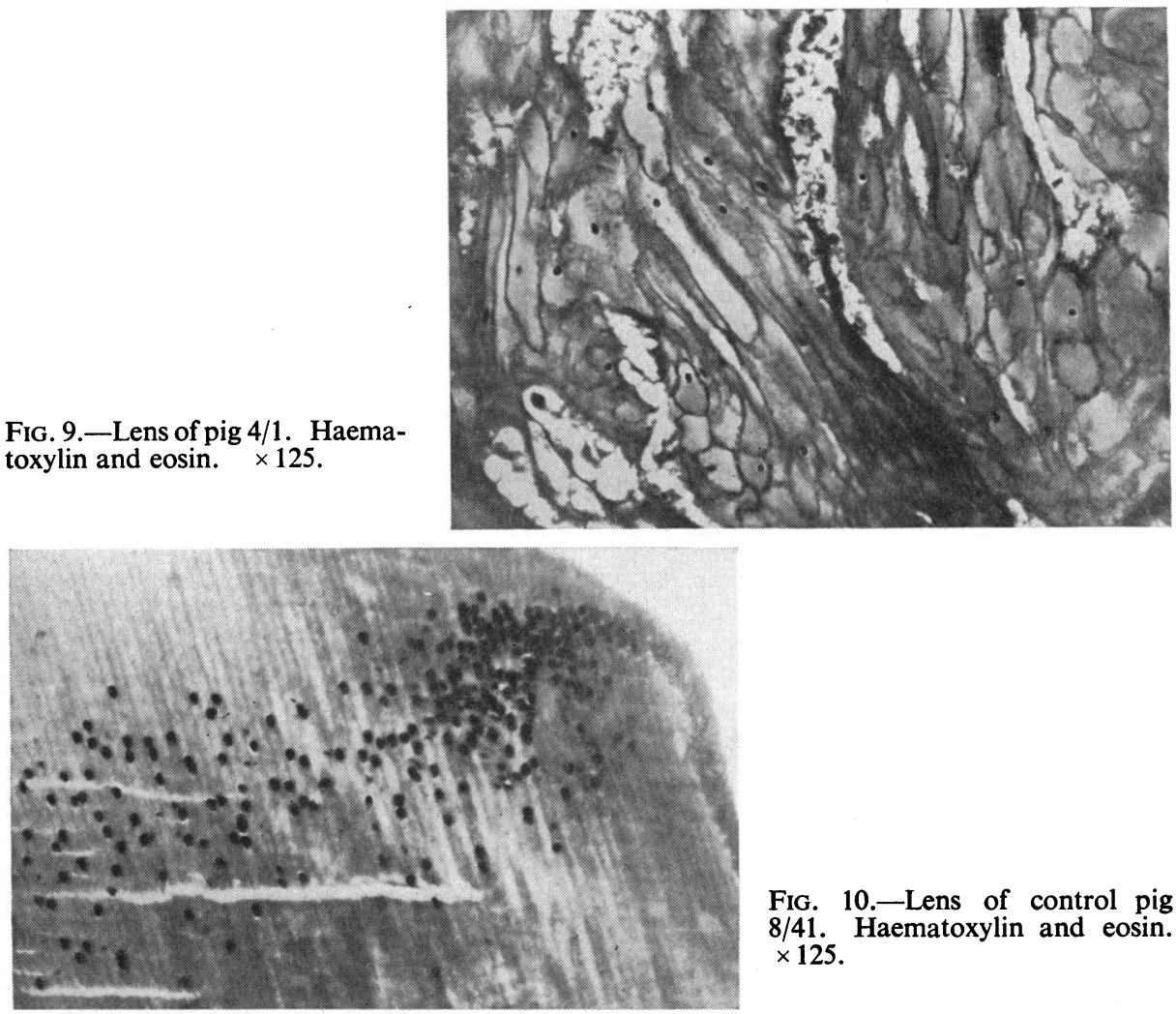

Fig. 10.-Lens of control pig 8/41. Haematoxylin and eosin. $\times 125$.

Complete degeneration of fibres resulted in the filling up of interfibrillar clefts with amorphous debris. Near the equator the fibres were affected in a characteristic manner, previously described by other workers, in various forms of injury to the lens, as "hydropic cells", "bladder cells", "bubble cells", etc. These are clearly shown in Fig. 9. The presence of a nucleus in some of the cells and of a double line in the common boundary between two cells showed that these were hydropic cells, and not merely interfibrillar accumulations of fluid.

The Harderian gland had a similar histological appearance to that of rats fed Diets 3 and 4 (Fig. 11, overleaf). This should be compared with Fig. 12 (overleaf) from a control pig. The cornea, retina, and other parts of the eye appeared normal.

\section{Discussion}

Elsewhere (McLaren, 1958b), the effects of low protein diets on the growth and water content of the eyeball of the rat have been discussed. Even on Diet 4 the eyeball continued to grow at about 75 per cent. of the rate of that of the age control and the water content was not materially affected. The failure to find clinical or histological changes over a period of 2 years 


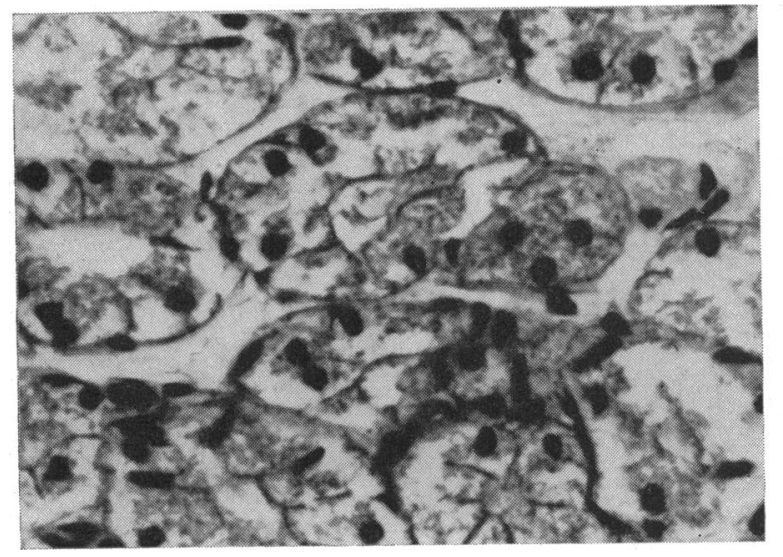

Fig. 11.-Harderian gland of pig 3/1. Haematoxylin and eosin. $\times 500$.

FIG. 12.- Harderian gland of control pig. Haematoxylin and eosin. $\times 500$.

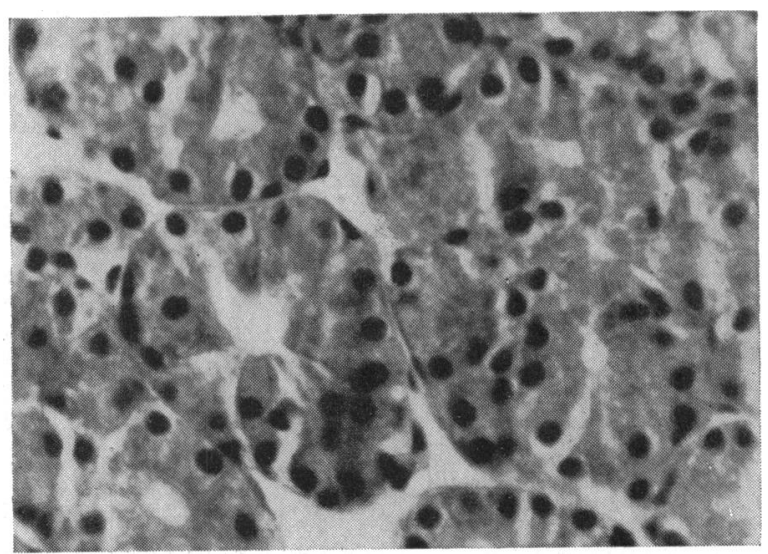

in the eyes of rats fed Diet 1 , supplying only about 4 per cent. protein, also indicates the resistance of the eye to protein deficiency.

The importance of the sulphur-containing amino acids for the cornea is demonstrated by the invariable occurrence of vascularization when these were very low, as in Diet 2. Very few analyses have been done of the amino acid composition of human dietaries, but the little evidence that there is would seem to suggest that methionine is the limiting amino acid. Groundnut and cassava are important dietary constituents in areas where there is much protein malnutrition, and these results may have significance in human eye disease.

The lesions described in the lacrimal and Harderian glands of rats and pigs are similar to those found in the pancreas in rats fed tropical dietaries in this laboratory (Balfour, 1954). They also closely resemble those seen in the pancreas, salivary, and lacrimal glands of children dying of protein malnutrition in Uganda (Trowell, Davies, and Dean, 1954).

The differences which occur between species are demonstrated by the greater apparent susceptibility to damage of the lens of the pig as compared 
with that of the rat on the one hand, and the number of corneal changes in the rat and absence of these in the pig on the other. In view of these differences between these two species it is quite impossible to draw any detailed conclusions with regard to the lesions that might be caused in the human eye by protein malnutrition. Furthermore, the diets used in these experiments were much poorer in protein than human diets are ever likely to be for any length of time. In these studies other factors, such as accompanying vitamin deficiency and trauma, were not thought to play a significant part, but in man dietary deficiencies are always multiple and injury and infection are frequent accompaniments.

This work should serve to discourage the claims, made on the basis of the results of animal experiments, that certain eye conditions of obscure aetiology occurring in malnourished communities are due to protein deficiency. Very careful studies in man will have to be done before this question can be answered.

\section{Summary}

It has been suggested that certain eye conditions of obscure aetiology, which occur in malnourished communities, may be due to protein deficiency. A study of the eyes of rats fed various diets very low in protein showed that changes developed in the cornea and the associated glands. In the proteindeficient pig cataractous changes occurred in the lens and the Harderian gland became atrophied. In view of the difference between the response to protein deficiency of the eyes of these two species, caution is urged in drawing conclusions regarding the effects of protein malnutrition of the eye in man.

This work was undertaken whilst the writer was a Colonial Medical Research Student and formed part of a thesis submitted in partial fulfilment of the requirements for the degree of $\mathrm{Ph} . \mathrm{D}$., University of London. The writer wishes to acknowledge the constant help and interest of the Director of the Human Nutrition Research Unit, Medical Research Council, Professor B. S. Platt, C.M.G.

\section{REFERENCES}

Balfour, B. M. (1954). "Malnutrition in African Mothers, Infants, and Young Children". Report of Second Inter-African (C.C.T.A.) Conference on Nutrition, Gambia, 1952, p. 120 . H.M.S.O., London.

Brock, J. F., and AuTret, M. (1952). "Kwashiorkor in Africa". W.H.O. Monograph Series, No. 8, Geneva.

Bruce, H. M., and Parkes, A. S. (1956). J. Anim. Tech. Ass., 7, 54.

Carturight, G. E., Wintrobe, M. M., BuschKe, W. H., Follis, R. H., Jr., Suksta, A., and HUMPHREYs, S. (1945). J. clin. Invest., 24, 268.

HALl, W. K., Bow'Les, L. L., Sydenstricker, V. P., and SCHMidT, H. L. (1948). J. Nutr., 36, 277.

KNOW'Les, C. B. (1957). Proc. Nutr. Soc., 16, ix.

MCLAREN, D. S. (1957). Ibid., 16, xxiii. (1958a). Bull. Wld Hith Org., 19, 303.

Platt, B. S., McLaren, D. S., and BaGCHI, K. (1957). Proc. 3rd Sess. CCTA Inter-Afr. Nutr. Conf., Luanda, 1956. In the press.

SYdenstricker, V. P., HALL, W. K., HocK, C. W., and Pund, E. R. (1946). Science, 103, 194. Trowell, H. C., DaVIES, J. N. P., and DEAN, R. F. A. (1954). "Kwashiorkor"' Arnold,
London. 